MARCH 15,1918 No. 5

\title{
BULLETIN
}

OF THE

SCRIPPS INSTITUTION FOR BIOLOGICAL RESEARCH OF THE

UNIVERSITY OF CALIFORNIA

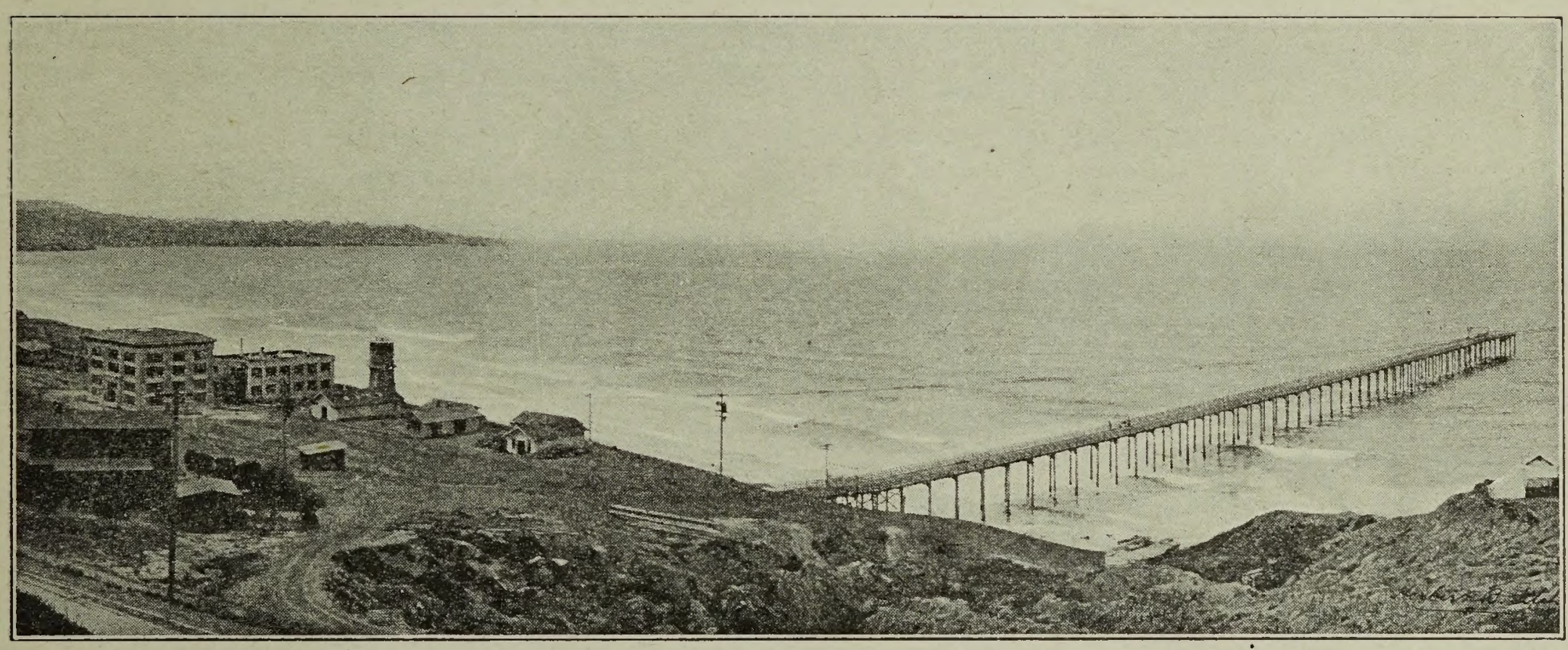

THE RESOURCES OF THE NORTH PACIFIC OCEAN: THEIR EXTENT, UTILIZATION AND CONSERVATION

BY

WILLIAM E. RITTER 



\title{
THE RESOURCES OF THE NORTH PACIFIC OCEAN: THEIR EXTENT, UTILIZA- TION AND CONSERVATION
}

\author{
By WILLIAM E. RITTER
}

1. Introductory statement.

2. Standpoint of the discussion.

3. Summary of North Pacific productions already utilized to some extent.

4. Special remarks on the food and a few other resources of the area.

5 . The question of permanence of such resources.

6. Some typical questions of abundance and conservation.

7. Is the North Pacific as productive from the fisheries standpoint as the North Atlantic?

8. Extensive scientific research the only way to answer the above question.

\section{INTRODUCTORY STATEMENT}

In accordance with a recommendation by the Committee on Zoological Investigation of the Pacific Coast Research Conference, working in co-operation with the Committee of Scientific Research of the State Council of Defense of California, the Research Conference adopted the following resolution at its meeting of November 24, 1917 :

\section{Resolution in Regard to Problems of North Pacific}

WHEREAs, the world-war has brought home to us as never before a realization of the necessity of full and accurate knowledge of our food resources and the necessity of developing and utilizing these resources to the maximum extent compatible with their adequate conservation; and

WhEREas, our knowledge of the fishery resources of the North Pacific is very imperfect and wholly inadequate to serve as a basis for trustworthy conclusions as to the extent and permanence of these resources, or as to what is necessary for their preservation; therefore, be it

Resolved by the Committee on Zoological Investigations of the Scientific Research Conference of the State Council of Defense of California that the proper department or departments of the United States Government be urged to take such steps as may be necessary to provide for a comprehensive and thorough exploration 
of the Pacific with a view to the development, greater utilization, and adequate conservation of its fishery resources of whatever kind, and that, if possible, such exploration be undertaken in co-operation with other governments possessing territory bordering the Pacific Ocean.

The aim of the paper herewith presented is twofold. It is, first, to give in very general terms certain reflections induced by the author's contact with the rapidly developing fisheries and kelp industries of the California coast during the last few years, especially since the United States entered the war; and, second, to make such presentation weigh as an argument on behalf of the resolution above quoted.

I wish to call special attention to the fact that while the paper naturally restricts itself almost entirely to the scientific and economic aspects of the subject, I recognize the legal and political aspects of it, especially as these involve international relations, to be quite as far reaching in possibilities as are the scientific and economic aspects.

It is a cherished hope of the writer that what is here said may catch the attention of some one competent to treat the other aspects and that such a treatment will be forthcoming in the near future.

At no time, probably, in the whole history of the human race have such numbers of it, both as to groups and as to individuals, been brought into such vital relations with one another in so many particulars as are involved in the present gigantic struggle at arms. What will come of it all?

- Is it chimerical to hope that the unifying forces rooted in what is common to the whole race, now so potent among the hundreds of millions of Europeans, Americans and Asiatics at war with the Central Powers, may be carried over to some extent into the post-bellum era as a beneficent legacy of the war?

The extent to which science has contributed and is contributing to the incalculable destruction and misery which civilization has brought upon itself is certainly one of the impressive lessons of this conflict.

But science will have to play as large a part in the period of reconstruction which must follow as it is playing in that of destruction which is now upon us.

The needs and opportunities pointed out and the proposals made in the paper accord with this constructive function of science, and it is earnestly hoped that in the near future, if not just now, the people of the United States, acting through their National Government, will make it possible to carry out some such enterprise as that suggested.

\section{STANDPOINT OF THE DISCUSSION}

The subject is viewed as one small aspect of the general problem of the actual physical needs of civilized man. 
The assumption is that civilization will continue to advance, that this will involve the continued growth of populations, and that this growth will necessitate finally a requisitioning of the latent resources of the whole earth to meet the necessities of peoples, as distinguished from their ambitions for gain.

These assumptions are justified by the facts of history and the nature of man.

Though healthy advance in civilization by a people whose death rate exceeds or equals its birth rate is conceivable, the history of human culture probably does not furnish an instance of such a thing. Anyway the well nigh universal rule is that peoples showing a vigorous cultural growth show also vigorous numerical growth.

Illustrations are numerous.

Europe's population more than doubled during the ninety-year period, 1801 to 1891 (175,000,000 in $1801 ; 357,000,000$ in 1891), probably very little of the growth being due to immigration. Besides this addition to her own numbers, the little continent furnished many millions, some 25 or 30 at least, to other continents, particularly to the Americas, Australia and Africa.

The very countries which have been front and center of the world's later progress in civilization have been also the swarmers for peopling the earth. But the case of Europe does not stand alone. The most advanced of all Oriental nations, the Japanese, are still more prolific. At present this nation is said to be doubling its population in about fifty, instead of ninety, years.

There are now undoubted signs that growth in civilization is to some extent a check on fertility, and consequently that such rapid increase of population of civilized countries as has characterized the later centuries will not be kept up. But, on the other hand, the staying of disease, famine, and infanticide, which in the past have been potent in keeping down population, are among the most prized and distinctive marks of progress. And now comes the possibility that the near future will see war, the fourth great check on population, shorn of its truly devastating power. All in all, the conclusion seems unescapable that high and ever higher world eivilization implies large and ever larger world population.

Having regard to these facts of population and to the limited size of the earth, and reflecting that advance in civilization is conditioned on nothing less than ever increasing richness of human life-improving physical health, and never ceasing intellectual, moral, esthetic and religious growth-and how avoid recognizing that in the future all economic endeavor and much of political endeavor will have to concern themselves far more positively and directly with the indispensable requisites of the great rank and file of populations than they have in the past? 
There can be no question that the demand for greater world democratization, which has become the battle cry for all nations now fighting German autocracy and miltiarism, is also the watchword of a great forward move in world civilization, and that one element in the success of the movement would be the death knell not only of irresponsible political rule but as well of irresponsible economic exploitation.

The indubitable needs of civilized peoples which in future will be the great inspiration of political action will have to oppose ambition for material wealth hardly less stoutly and vigilantly than it will have to oppose ambition for dynastic and militaristic power. And this will bring a change over nearly the whole of economic theory, purpose and method.

Among the foremost of these changes one will concern the way the yet undeveloped resources of nature are viewed. Science under govermmental support rather than private industrial enterprise will become more and more the exploratory agency of latent economic resources, and developmental projects will be timed and carried out as far as possible in accordance with needs as calculated on scientific rather than wealth-yielding principles.

Another of the changes will affect the terms in which resources are expressed. These terms will be more and more those of use values rather than of money values. Treatises on industrial production and trade will be more concerned about the articles made and bought and sold, their quantity and uses, and less about their trade prices and money values. The experiences of the great war are indicative of what the future has in store for the world in this respect. The public will of course always be much concerned about the price of commodities, but it will become likewise more solicitous about questions of source and supply, and will think more about the significance of price as an indication of supply than it has been wont to do. I mention these two particular changes of viewpoint because they will be reflected in the discussion which follows.

The landed areas of the earth undoubtedly always will be, as they always have been, the main sources of the food, clothing and other material goods needed by man; so agriculture, mining, water-power development, lumbering, and so on, will probably ever be the supreme raw-material industries and sciences.

But-and we here approach our subject proper-the waters of the earth-the rivers, lakes and oceans-are now well known to science to be capable of yielding vastly greater quantities of food and other necessaries of human well-being than have yet been developed. Sir John Murray, one of the most learned of all students of the sea and its inhabitants, expressed the view that the total organic productivity of the earth's waters is probably considerably greater than the total 
productivity of its lands. Now any one acquainted with the uniformity there is in the basic substances of all life cannot fail to recognize, on a little reflection, something of what this productivity of the waters means in the way of possible sources of human food. It means that under anything like great pressure of population on food supply it would be only a question for science and industry to find ways of utilizing these resources.

And here we come upon a very important aspect of science's part in solving the problem of supplying man's physical needs, namely, its part in molding custom in accordance with reason and definite knowledge, rather than permitting it to be determined by whim and prejudice and fashion and trade interests.

The experimental food laboratory will undoubtedly play a much larger part in the future than it has in the past in determining what plants and animals are available for human nutriment. The era of deciding whether or not a given animal is fit for food, on the basis of such whimsicalities as whether it chews the cud or has cloven feet, or is taken in a month with no $r$ in it, is drawing to a close for civilized man.

3. SUMMARY OF NORTH PACIFIC PRODUCTIONS ALREADY UTILIZED TO SOME EXTENT

But with the general problem of resources of the sea and human needs we are concerned only as a background for treating a special case. Our purpose is to present a few considerations touching the resources of a single economic area, the North Pacific. An inventory of resources of this region, drawn up on the basis of actual observation and experience, follows:

\section{Human food.}

Fishes: salmon, halibut, cod, tuna, sardine, flounder, sole, rockfish, barracuda, herring, bonita, mackerel, yellowtail, sanddab, grayfish, smelt, swordfish, anchovy, cultus cod, seabass, rockbass, and many others less important.

Mollusks, crustaceans, etc.: oyster, crab, spiny lobster, shrimp, clams (many species); mussel, abalone, squid, beche-de-mer.

Turtle.

Marine algae: several species.

2. Agricultural fertilizers.

Many kinds of seaweeds, particularly kelp, refuse from all commercial fishes, many kinds of fish not utilizable for food, refuse from whales, turtles and fur seals.

\section{Food for fowls.}

Refuse from commercial fishes and certain species of fishes not available for human food. 


\section{Clothing.}

Fur seal; whale, porpoise and shark skin for leather; sea otter for furs; abalone and other mollusk shells for buttons; marine algae for bandoline, sizing and stiffening for cloth and paper.

5. Oils.

Whales and various species of fish.

\section{Ornamentation and industrial arts.}

Pearl oyster and abalone for pearls; various molluscan species for shell ornaments and inlay work, shells for various domestic articles; seaweeds for bric-a-brac, etc.

\section{Chemicals.}

Algae, many species, for agar-agar and other gelatine media, alginate, potash, iodine, acetone, acetate, ketone, etc.

\section{SPECIAL REMARKS ON THE FOOD AND A FEW OTHER RESOURCES}

\section{OF THE AREA}

By far the most important single food fish so far utilized is the salmon. The total product for the whole Pacific coast of North America from this source for 1915 was approximately $625,000,000$ pounds of fresh fish.

There is considerable reason for doubting whether much increase of production from this source is possible, or at least practicable. The output of the salmon industry has been, with much fluctuation, practically stationary for some years, though the producing capacity of the equipment engaged in the industry has probably at no time been taxed to its limit. In other words, increase of effort in the industry would apparently not be able to increase greatly the output.

The fish next after the salmon in productivity is now, it seems, the sardine. The pack of the first six months of 1917 was about $1,800,000$ cases, giving a total estimated weight of fresh fish utilized for this pack and for other purposes of $145,000,000$ pounds. There is no doubt about the possibility of further increase of product from this fishery. Mr. N. B. Scofield of the California State Fish and Game Commission has expressed the view that the California fishery will soon equal, at least, that of Maine, which is about 2,500,000 cases annually.

After the sardine, perhaps the most productive single species is the halibut of the Washington-British Columbia-Alaska coast. This is in the main a fresh and frozen producy industry and bulk weights are given. The figures are for 1915: Oregon-Washington-British Columbia to Alaska, 56,250,000 pounds fresh fish. The future possibilities of this source of fish food is problematical. As we shall see later, an urgent problem of conservation is already on hand in connection with this fish.

Very close in importance to the halibut as a food fish comes the long-finned tuna, or albacore, of the southern and Lower California 
coast. Indeed, if along with this species there is taken its several relatives-the bonita, the yellow-finned tuna, the chub mackerel, and the yellowtail - and prospective as well as actual production be considered, the group may turn out to be second to the salmon only in importance. Four hundred thousand cases, or about $48,000,000$ pounds of fresh fish, is the estimated pack for 1917. There is no question that with improved methods of fishing the product from this source would be greatly increased-doubled at least. By far the larger part of the quantity now produced is from one species, the long-finned tuna. But two or three of the related species are probably not less abundant, so only await exploitation.

This very imperfect statement of a few of the main sources of fishery foods now yielded by the northeastern Pacific must suffice for the analytic part of our treatment. The estimated grand total animal product, that is, the product including not only the portion we have partially analyzed, but all the rest, will conclude this part of our story. According to Mr. F. W. Bailey, formerly secretary of the California State Fish Exchange, about 100,000,000 pounds, or 50,000 tons, of food fish were handled by the commercial fisheries of California alone during the year 1916.

From all these figures and others not here used it appears that the total fresh fish production of the Pacific coast is now not far under $1,000,000,000$ pounds annually. Considering the imperfect state of development of several of the fisheries contributing to the present output, notably the cod and herring fisheries of Alaska, and the bonita, mackerel, yellowtail, barracuda, and anchovy fisheries of southern and Lower California, and the obvious possibilities of several animals, notably the squid, the mussel, the turtle of Lower California, and the fur seal, the porpoise and the whale, now practically untouched for food, it is not beyond bounds to estimate that this could be doubled during the next ten years, and the total for the coast brought to $2,000,000,000$ pounds, or $1,000,000$ tons, annually were there real demand for such a quantity.

Casting up the whole account, actual and prospective, of meat food production from the ocean of this part of the earth, and speaking in the light of experience with fishery food by such peoples as the Scandinavians and the Japanese, we shall be on safe ground if we say that were the land-produced meat supply of North America to become seriously insufficient for the population, the deficiency could be made good to a large extent from the fisheries; and to the supplying of this deficiency the fisheries of the Pacific could contribute their proportion. Thus is brought to our attention in a rough and ready, though I believe entirely trustworthy way, a large, readily available supplement to this continent's meat supply. 
Nor is it to be forgotten that America's part of the great ocean has long contributed, is now contributing, and unquestionably might contribute in still larger measure to satisfying other needs of man than that of food. Details on this aspect of our subject, though full of interest, must be even more summary than that on food.

Barely touching the contributions of the fur seal to human clothing, I mention the successful protective measures now being carried out through international treaty, and call attention to the certainty, almost, in the light of the history of the fur seal industry, that the herds of this useful animal might be made productive in number of pelts beyond what they have ever been, even before their original depletion while they were under Russian ownership. The fur seal comes nearer, perhaps, to domestication than any other oceanic animal.

The only other latent source of human clothing from marine life, which I mention, is that of leather from whales, porpoises and sharks. Important developments in this direction seem likely.

Although several other human needs to which, as pointed out, the animal and plant life of the Pacific are capable of contributing, ought each to receive a few paragraphs at least, in even a summary paper like this, the space at my disposal compels me to psis them by with only a lump reference to them.

\section{THE QUESTION OF PERMANENCE OF SUCH RESOURCES}

This question comes up immediately when one considers seriously the utilization of these resources on an enlarged scale.

Nothing is more obvious than that man's control over the animal, or even the plant life, of the sea has not reached, indeed, almost certainly never can reach, any such effectiveness as that which he already exercises over the useful species of the land. Except for certain actually and potentially important animals and plants, as the salmon, shad, oyster, clam, lobster, crab, abalone, and possibly some algae, which inhabit the littoral, or near-shore zone, there is no present outlook for man to do much in the way of domesticating and breeding marine species. His utilization of nature's bounties in this realm will probably continue to be, as it always has been, chiefly through his labors as a harvester, rather than as a cultivator. So far as the great oceanic waters are concerned, there is not much prospect for aquiculture comparable with agriculture.

As to the main resources of the sea, industry and science are occupied with native or wild species almost exclusively, rather than with artificial or tame species, as they are in agriculture. In other words, the problems dealt with are zoological and botanical in the strict sense far more than are those with which agriculture deals. 
'This means that the industries concerned with the utilization of marine life are much more problems of conservation of wild life than is agriculture, and hence must occupy themselves much more with such purely zoological and botanical subjects as geographical distribution, breeding habits, migration, ecological interdependence and succession, and taxonomy.

With these general principles in mind, we can now state in general terms what the question of permanence of the food and other economic resources of the sea really is. It is a question of the goographic range, density of population, environic conditions, and propagating habits of the various species figuring in the industries.

\section{SOME TYPICAL QUESTIONS OF ABUNDANCE AND CONSERVATION}

For the rest, we touch upon some of the main problems of supply, approaching these through the zoological principles just mentioned; and some of the legal and political problems that would necessarily be involved in protective measures, should such be found useful.

First, I illustrate from Pacific Ocean experience, brief and meager as that has been, something of what zoological research has already done in connection with fisheries and kindred industries.

The apparently effective hold government has at last secured on the problem of the Alaska fur seals rests mainly on the investigations of Elliott, Merriam, Townsend, True, Evermann, Jordan, Stejneger, Lucas, Clark, Osgood, and Parker, confining the enumeration to American zoologists who have studied the animals during the period of their American ownership.

The basis for an intelligent general management of the salmon industry is securely laid in the scientific researches of Jordan, Gilbert, Evermann, Rutter, Babcock and others. The practical significance of scientific knowledge for fisheries receives striking illustration in the salmon industry by the foreseeing, months beforehand, of the probable small run of the sockeye salmon at Puget Sound during the summer of 1917. That the run of this species, which has been the backbone of the salmon canning industry on the Sound, is especially large every fourth year, is so well confirmed as to be accepted as a rule for guiding the plans of the operators. Since the last large run was in 1913, the next large run was due last summer, 1917. But in 1913 a great earth slide on the Fraser River, the chief spawning stream of the species, interfered so seriously with the ascent of the salmon as to arouse apprehension lest the special run of 1917 would be prevented.

Because of the comprehensive investigations on the habits of this and other species of the Sound region by C. H. Gilbert and J. P. Babcock, it was possible to submit this apprehension to searching examination. This was done and confirmation was reached that the extra 
harvest otherwise due in 1917 would not materialize; and such proved to be the case, as the estimated sockeye pack for the season of 1917 is only 170,000 * cases, which represents only 25 per cent of the sockeye pack of 1913. Although I have no information on the point, probably those interested in the industry were able, through this forecast, to mitigate their loss to some extent.

Another example of the importance of zoological investigation for industries based on marine animals is furnished by the whales of the northeast Pacific. Were these mammals to come into new importance as sources of articles needed by man, as they bid fair to do, the problem of their conservation would come up immediately. We possess considerable scientific knowledge from which to start for intelligent action in this behalf. This knowledge is due, interestingly enough, to the circumstance that a practical whaler of the former whaling era turned zoologist and did a masterly piece of research work on the animals concerned. I refer to Captain Charles M. Scammon and his monograph, "The Marine Mammals of the North-western Coast of North America.' With such aid as he could get from professional zoologists, notably W. H. Dall, Scammon produced a work that must elicit the admiration of every true student of animal life, and will never become much out of date no matter how many centuries the science of zoology continues to advance.

Finally, we cite the carefully worked-out demonstration by W. F. Thompson that the halibut fishery of the northwest coast is surely undergoing depletion and the seemingly rational conservation measures proposed by him.

So we resume consideration of the question of permanence of food and other maritime resources with a clearer perception that the problem is one the treatment of which depends largely on zoological knowledge.

Let us notice a few fundamental zoological principles applicable to the problem. First, every animal and plant species whatever is territorially limited at any given time. Perhaps this seems so like a truism as to render mention of it unnecessary. But active attention to it is important both on scientific and industrial grounds; and that as a practical fact it receives scant consideration by most persons I have had frequent opportunity to notice.

A second of these principles is that, speaking broadly, the number of individuals of a species existing at one time varies inversely as the size of the individuals. This rule is subject to great modification, but if taken with the intelligent caution essential to the application of nearly all rules of organic beings, it is unquestionably a useful guide. In the absence of definite knowledge to the contrary we should expect

\footnotetext{
*Pacific Fisherman, November, 1917.
} 
the total number of the huge sulphur bottom whale to be less than the total number of porpoises; the total number of porpoises to be less than the total number of tuna; the total tuna population to be less than the total sardine population; the grand total of sardines to be less than the grand total of shrimps, and so on through the whole animal kingdom. The applicability of this principle is obvious. By way of illustration there is more reason for solicitude other things being equal, about the supply of tuna than of the sardine. Other things being equal, there is more likelihood of depleting the supply of halibut than of sole; and so on. Confirmations of this rule are probably numerous. The diminishing halibut supply of the northwest coast is in point. But one of the most striking cases is furnished by the whales.

The whaling industry of the United States when at its climax, about 1846 , constituted an appreciable fraction of the whole industrial life of the nation, as is recorded in the number of animals taken. According to statistics given by Scammon, between 1835 and 1876 more than 292,000 whales were destroyed. But this destruction went well toward depopulating the sea of these great beasts. That 730 ships with an aggregate tonnage of 233,189 tons, and 70,000 people were engaged in the business in 1846, objectifies sharply the magnitude of that one productive capacity of the sea. The practical lesson for us will not be missed: If whaling should again become a significant industry on our coast, restrictive measures would be necessary almost at once if the supply is to be kept up to even its present standard, which is surely much below what it was before the great depletion due to the former period of California shore whaling.

The principle governing supply next to be mentioned is that of extent of territory inhabited by a species. This varies enormously with different species of animals, being almost world-wide with many marine species, especially of the lower orders; and quite restricted with many others. Other things equal, obviously a species widely distributed would be more abundant in individuals and hence less subject to depletion through capture by man, than one of restricted distribution. Speaking generally, high-seas, or pelagic species are much more widely distributed than are species confined to coastal waters, whether living on the bottom or as free swimmers. And it is universally recognized that the pelagic species of fishes are pre-eminently the ones least liable to suffer from over-fishing.

But the two principles, size of individuals and geographic range, are so inextricably connected with the rate of propagation that neither can really be considered apart from the whole round of reproductive and growth phenomena. The chief reason for mentioning them separately is that though the whole reproduction complex has to be taken into account finally, it often happens that an investigation of a species reaches quite full knowledge under one head before it knows much 
under other heads; and by having these principles in mind useful conclusions may be drawn.

Take for example the case of the California gray whale. The fact of its being so large would of itself be sufficient to justify the supposition that its numbers are small as compared with any species the size of whose individuals is but a small fraction of the size of the whale. But supplementing this knowledge as to size with the fact, discovered with much more difficulty, that its geographical range is small as compared with the range of most whales (it is restricted seemingly to the coastal waters of western North America), puts an additional curtailment on its probable total numbers, and makes it, by so much, more liable to extinction through unchecked pursuit, regardless of whether we know its breeding habits or not. As a matter of fact this species seems to have been almost exterminated by the previous whaling period and measures should be taken at once to ascertain its present abundance and to regulate the killing of it in accordance with the findings.

We now turn to the more general problem of quantity and exhaustibility of economically important marine species.

The diversity of view on this subject, even among those who have studied it extensively, is surprising. One of the most distinguished American zoologists and students of fisheries, Spencer Baird, wrote at the conclusion of an extensive inquiry into the fishing industries of the New England coast: "It is difficult to point ont any locality where near the shores in the New England states, at least, under the most favorable view of the case the fish are quite as plentiful as they were some years ago.',

Summarizing the conclusions drawn from a ten-year continuous experimental inquiry carried on under the Sea Fisheries Amendment Act of Scotland on the quantitative effects of steam trawling, Garstang and Mitchell say : "The results of this classical experiment point strongly to the presumptions (1) that trawling operations in the open sea have now exceeded the point at which their effect on the supply of eggs and fry for the upkeep of the flat fisheries is inappreciable; and (2) that protection of in-shore areas alone is insufficient to check the impoverishment caused by over-fishing off-shore."

Marcel S. Herubel, in "Sea Fisheries: their Treasures and 'Toilers," expresses the unqualified view, supported by considerable statistical evidence, that the fisheries of various parts of the French coast, in both the Atlantic and the Mediterranean, are being impoverished by the industries, the statement having reference mainly to bottom-dwelling species.

Perhaps the opinion on this matter most widely known among English speaking peoples is Huxley's. His conclusion, based on experience gained as a member of various commissions for inquiring into 
the conditions of British fisheries, was, in brief, that while certain shore and river fisheries like those of the salmon and the oyster, are unquestionably exhaustible, with fisheries of the open seas the case is different. "I believe then,' he said, "that the cod fishery, the herring fishery, the pilchard fishery, the mackerel fishery, and probably all the great sea-fisheries, are inexhaustible; that is to say, that nothing we do seriously affects the number of the fish. And any attempt to regulate these fisheries seems consequently, from the nature of the seas, useless." (Inaugural Address: Fisheries Exhibition, London, 1883.) The observations and calculations given by Huxley in support of this opinion are undoubtedly weighty. A single pair of codfish, for example, of the coast of Norway, he points out, on the basis of data which seems trustworthy, would considerably more than supply the whole of the codfish taken by all the Norwegian fisheries put together in one season.

And a still more recent authority, W. C. McIntosh (The Resources of the Sea, London, 1899, reaches a conclusion against exhaustibility still more sweeping than Huxley's: "So far as history and so far as observations at the present time go, there is no ground for alarm in regard to the permanence of the food-fishes" (p. 234). And this applies to the sole and other flat fishes near shore as well as to the high seas species mentioned by Huxley. McIntosh's conclusions are noteworthy because based to a considerable extent on a re-examination of the same data from which a report of contrary tenor had been drawn by the Fisheries Board for Scotland.

And so experienced fisheries authorities as the Norwegians, Hjort and Dahl, say (Report on Norwegian Fishery and Marine Investigations, Vol. I, 1900, no. 1) : "It is impossible to imagine that any decline can take place in the stock of fish which, in any case during a great portion of its existence, belongs to the open sea. No mention has ever been made of any decrease in the yield of the bank round-fish fisheries of the country. . . . The general desire, a desire which receives unanimous support, is certainly only that of enlarging them to the greatest possible extent.",

"The Lofoten fisheries, which have been carried on for hundreds and hundreds of years, certainly exhibited in former days as great variations in their yield as they do now, and no proof whatever exists of lesser abundance, now than formerly, of the cod which visit the shores of the Lofotens, and very many other parts of our coast during the spring"' (p. 180).

On the whole the fullest and most trustworthy experiences the world has so far had on marine fisheries seem to indicate that while depletion of various kinds of near-shore and sea-and-river inhabiting species, is likely to occur in particular localities, with species which 
belong primarily to the open ocean, such a result is practically beyond the power of man.

The general conception about the oceanic species is that their number and the number of their eggs and young is so vast, and belong to so vast a system of interdependent organisms-a system in which so many kinds are at once feeding upon and being fed upon by one another, that the little that man can do, either by way of destroying or replenishing, is negligible. Otherwise expressed, the "balance of nature" is on so prodigious a scale in the sea that man, operating under the limitations imposed upon him by sea-faring conditions, can have no effect. His interventions are powerless to change the course of nature in this as they are to change the tides, is McIntosh's way of stating the view. The ocean is looked upon as a mighty reservoir of life as well as of water, the former being little, if any more exhaustible by man than the latter.

\section{IS THE NORTH PACTFIC AS PRODUCTIVE FROM THE FISHFRIES STANDPOINT AS THE NORTH ATLANTIC?}

Coming back to our subject proper, that of the resources of the North Pacific, I call attention to the fact that the conclusions set forth above relative to the inexhaustibility of oceanic fisheries are based almost entirely on experiences in the Atlantic; and that the conditions presented by the Pacific are sufficiently different from those of the Atlantic to make it unjustifiable to apply to Pacific fisheries ronclusions which may hold for Atlantic fisheries.

I am anxious not to be misunderstood at this point. The above statement should not be taken to mean that I consider it very probable that the commercial fishes of the Pacific are less in bullk than are those of the Atlantic. I want to go no farther than is indicated by the exact language. Oceanographically the North Pacific is a quite different body of water from the north Atlantic; and the difference is of such character as to make it possible, indeed rather likely, that the North Pacific is on the whole somewhat less prolific of life than the corresponding part of the Atlantic.

All I want is to convince those interested in the fisheries of the Pacific coast of North America, and scientific men generally, that the question raised is one which, from both economic and scientific considerations, is of much interest, and indicates the need of far more extensive knowledge of the Pacific and its life than we now possess.

Before enumerating the conditions which suggest such a difference of productivity of the two oceans, I mention that some naturalists have surmised such a thing on the basis of more special considerations than those here set forth. Thus Steuer: "Since the neritic (near-shore) plankton flows from the shore toward the high seas like an inexhaust- 
ible stream the seas and portions of the seas northward from the equator appear richer than those southward therefrom; likewise the Atlantic seems richer than the 'great ocean',' (A. Steuer, Planktonkunde, p. 457). And some of the naturalists of California who have had first-hand experience with the plankton off the California coast have an impression, vague to be sure, to the same effect. But, on the other hand, there is evidence of rather exceptional riches of plankton in some parts of the North Pacific. Viewed from any direction, the need of extensive researches is manifest.

Stated in barest outline, the oceanographic facts which warrant such conjecture about the productiveness of the Pacific are: Not only is the North Pacific a much larger expanse of water than the North Atlantic it is a more uniformly deep body; and since the principle seems well established that although there is no part of the ocean too deep or too remote from the continents to be inhabited by animals, the deeper the water the less the bottom population per unit area. There are many and important exceptions to this rule, but its general truth is indicated by the quantitative study of many dredgings and trawlings from widely separated parts of the ocean. And the suggestion: based on these hydrographic considerations, that the bottom fauna of the Pacific may be somewhat less abundant than that of the Atlantic, is confirmed, perhaps, by the fact that the bottom deposits of the Pacific are, according to our present knowledge, somewhat less rich in organic remains than are those of the Atlantic.

But if there is such a difference between the bottom faunas of the two oceans it may be reflected in the pelagic fauna, since it is established that there is more or less interdependence between the two. One aspect of this interdependence, that, namely, of the to-and-from shore migration of various pelagic species of commercially important fishes, the Scombroids, for example, is especially significant from the economic stand point.

But the most striking oceanographic differences between the northern parts of the two oceans are such as to suggest more direct influence on the pelagic than on the bottom life.

The first of these to be mentioned is the fact that the North Pacific is so much more nearly severed from the Arctic than is the Atlantic. That the colder seas are richer in plankton than the warmer seas seems definitely established. Numerous investigators of the pelagic life of the north Atlantic (Brandt, Nansen, Nathansohn) have dwelt upon the great productivity of the arctic polar currents. The East Greenland current which brings arctic water into the North Atlantic, and into the North Sea past the north of Iceland; and the Labrador current which brings arctic water far down the east coast of North America, are without counterparts in the North Pacific. Even the Oya siwo of the east coast of Asia is not really an artic current. 
But more important than the currents, according to some authorities, is drift ice. That this reaches well into the Atlantic off the American coast and well into the North Sea off the European, is generally known. The Pacific receives no drift ice at all from the Arctic, and very little, relatively, from any source in the northern hemisphere.

Why cold water, cold currents, and drift ice make the sea more productive, need not be considered for the purposes of this paper. The question has not as yet been answered quite satisfactorily, but as to the fact there seems no doubt.

Another oceanographic peculiarity of the North Pacific which probably has important bearings on its planktonic productivity, is the quantity of river water it receives.

One of the striking features of the North American continent is the fact that so large a proportion of its drainage is toward the east, into the Atlantic. At least two-thirds of the area of British North America, the United States, and Mexico drain into the Atlantic, and the average annual precipitation is probably considerably greater per unit area for the Atlantic than for the Pacific catchment region.

It is definitely known that rivers, especially those whose courses are through areas of rich land vegetation, contribute to the fertility of the sea by the organic matter carried by their waters. But it is a conspicuous fact that the stretch of Pacific from San Francisco Bay southward to Cape San Lucas, the southern limit of Lower California, a distance of some 1100 miles, does not receive a single river of consequence, the adjacent land being exceptionally arid.

Undoubtedly the problem of the place filled by nitrifying and denitrifying bacteria in the "metabolism" of the ocean, especially in regions which receive large quantities of organic matter from the land, is very imperfectly known. But it would seem evident that two oceanic areas so different as those of the Atlantic and the Pacific contiguous to the North American continent in respect to the quantity of fresh water received by each; in respect to the difference of circulation in each; and in respect to the amount of evaporation from each, would present important differences in the totality of their plant and animal life. And the phenomenon of upwelling water on the California and Lower California coast introduces a unique factor into the problem for the American Pacific region, which may prove of high economic as well as scientific importance, especially, perhaps, from its fertilizing effect on the waters. This phenomenon is without a counterpart, apparently, in the North Atlantic.

If the question be asked whether there are indications in the pelagic life itself that the North Pacific is somewhat less productive than the North Atlantic, attention may be called to two facts which may be so interpreted. These are the relatively slight development of the Sargasso sea in the Pacific; and the great area of "red clay" bottom 
deposit in the North Pacific in contrast with the "globigerina ooze" as the corresponding deposit in the Atlantic. Since these bottom materials are held to be the result of the deposition through countless ages of material from the superincumbent water, and since "red clay," the characteristic deposit of the North Pacific, is predominantly inorganic, while the characteristic deposit of the North Atlantic is predominantly organic, it is natural to conclude that the Atlantic has been producing somewhat more organisms through the ages than has the Pacific. Undoubtedly other factors might come in to modify these indications. For instance more volcanic activity in and around the margins of the Pacific may have increased the amount of atmospheric dust which has fallen upon the water, and thus account for the "red clay" bottom. But again it might be supposed that this inorganie excess for the Pacific would be met by the relatively greater inorganic sediment of Atlantic water, due to the greater quantity of river water poured into it. And still other alternative possibilities are presented by the known differences.

\section{EXTENSIVE SCIENTIFIC RESEARCH THE ONLY WAY TO ANSWER}

\section{THE ABOVE QUESTION}

Enough has been said, however sketchily, to make certain the purely scientific interest of the oceanographic and biologic problems of the North Pacific. But now that the entire northeastern portion of the area has come into economic prominence from the development of fisheries and kelp industries, the problems become doubly important and call more insistently than ever for investigations on so comprehensive a scale as to be beyond the reach of any other support and control than those of national governments.

Nor do the scientific and oceanographic problems thus far ontlined comprise all those that pertain to the Pacific.

Other fields of science would, or might, participate in such explorational studies as are suggested.

Undoubtedly various meteorological problems of importance, especially in their bearing on the climate of North America, could be investigated in connection with the undertaking. Reference to some of these has lately been made by Dr. Charles F. Marvin, Chief of the U. S. Weather Bureau, in supporting an earlier proposal for exploring the Pacific. Speaking of certain much needed investigations on the movements and stratification of the upper air, Dr. Marvin said: "No other observations are more urgently needed in meteorology at the present time than these, and it is difficult to conceive of a better field for conducting such explorations on a broad and all-pinclusive plan and scale than the Pacific." And I know from conversations with several meteorologists who have given attention to west American meteorology 
that there are other problems than that mentioned by Dr. Marvin, which calls for studies in the central and northern North Pacific especially.

Geodesy and geology are other sciences some of whose problems seem specially susceptible of illumination from investigations in the Pacific. Professor John F. Hayford has lately presented cogent reasons why the Pacific is more important than any of the oceans for gravity observations at sea. (The papers of both Marvin and Hayford are in the Proceedings of the National Academy of Sciences for 1916, Marvin's, p. 421, and Hayford's, p. 394.)

And this does not exhaust the list of sciences which could join with benefit in such researches.

Finally, in order that one of the most vital, though least dweltupon, matters of the paper shall not be lost sight of, I conclude as I began, with a reference to the essentially international character of most of the subjects presented.

The possible benefits, on account of the economic and scientific bearing alone, which might be realized from the execution of a project like that contemplated, are undoubtedly great. But I believe those latent in it, as bearing on the relations among the peoples and governments which ought to be, and from the nature of things would be, implicated, are not less great.

The interests of the United States, Great Britain, and Mexico are particularly close. But those of Japan are by no means remote and inconsiderable. Nor can those of Russia be ignored. 